\title{
Bone Marrow Derived Mesenchymal Stem Cell Therapy in Induced Acute Renal Injury in Adult Male Albino Rats
}

\author{
Abd Elwahab SA ${ }^{1 *}$, Hussein Ali A ${ }^{1}$, Sayed Mahmoud A ${ }^{1}$, Fathy Ahmed A ${ }^{1}$ and Reda Soliman ${ }^{2}$ \\ ${ }^{1}$ Department of Histology, Faculty of Medicine, El-Minia University, Egypt \\ ${ }^{2}$ Department of Clinical Pathology, Mansura university, Egypt
}

\begin{abstract}
Background and objectives: Acute renal injury (ARI) is a serious clinical problem without established regimen for treatment. Mesenchymal stem cells (MSCs) are undifferentiated cells that can differentiate and give rise to other cell types. The aim of the present work is to study the possible therapeutic role of MSCs in the treatment of the deleterious changes occurred in renal cortex and medulla of adult male albino rat model of ischemia/reperfusion (I/R) ARI.

Material and methods: Forty adult male albino rats were used in this study. Animals were divided into four groups, 10 animals for each group. Group I is control sham-operated group. Three experimental groups were all subjected to $\mathrm{I} / \mathrm{R}$ injury by clamping both renal pedicles for $40 \mathrm{~min}$. These animals were further divided into three subgroups. Group II is non-MSC treated group. Group III (MSC treated group (local injection)): I/R animals received bromodeoxyuridine labeled BM-MSCs locally in renal cortex immediately after removal of the clamps and confirmation of reflow. Group IV (MSC treated group (systemic injection)): I/R animals that received single intravenous injection of bromdeoxyouridine labeled BM-MSCs in tail vein immediately after removal of the clamps and confirmation of reflow. Animals were sacrificed after 3 days of intervention. Serological measurements included serum urea and creatinine. Kidney specimens were processed for H\&E, PCNA and Caspase-3. Real time RT-PCR study was done for TNF $\alpha$ and IL-6 gene expression.
\end{abstract}

Results: Cortical and medullary renal tissue exhibited marked improvement histologically and serologically after MSCs treatment. The improvement was more obvious in case of systemic treatment.

Conclusion: The present study shows the ability of MSCs to repair the structural and functional renal damage after I/R, Systemic route is more beneficial than local route. This may pave the future for therapeutic use of MSCs in the treatment of acute renal injury.

Keywords: Acute renal injury; Ischemia reperfusion; Mesenchymal stem cells; Proliferating cell nuclear antigen

\section{Introduction}

The kidney is a very specialized organ; histological structure of the kidney shows more than thirty different cell types. Each cell type has its own proliferation rate and regenerative capacity [1]. Epithelial Cells lining inner layer of the Bowman's capsule "podocytes", have no proliferative capacity [2]. If these cells are lost, they cannot be replaced [3]. Cells of the proximal tubules have a low physiological turnover capacity. Upon pathological damage, these tubular cells respond with diffuse proliferation [1].

Acute kidney injury is a medical emergency characterized by rapid deterioration of renal functions as a result of kidney damage, with accumulation of the nitrogenous compounds (urea and creatinine) and non-nitrogenous waste products that are normally eliminated in urine [4]. In severe cases, metabolic acidosis hyperkalemia, and changes in body fluid balance may be observed. Oliguria or anuria is the most common symptom [5].

Acute renal failure is mostly the end result of Ischemia-reperfusion (I/R) injury of the renal tissue. Its pathogenic events include acute tubular necrosis, apoptosis, glomerular injury and inflammation. It is characterized by sharp decline of glomerular filtration rate (GFR), is a very common complication in hospitalized patients and particularly in patients with multiorgan failure. Although it develops most frequently in multimorbid patients, its occurrence increases the risk of death by 10 to 15 folds [6]. This unacceptable situation warrants the urgent development of new treatment modalities.
Mesenchymal stem cells of Bone marrow-derived are multipotent stromal cells, which can give rise to osteocytes, chondrocytes, and adipocytes. Recent studies showed their capacity to give rise endothelial, myocardial [7], liver [8], renal [9], and pulmonary epithelial cells [10].

Mesenchymal stem cells have also been shown to have reparative, regenerative and immunomodulatory properties [11] and express growth factors known to be renoprotective in experimental ARF [12]. Stem cell-based approaches have enormous potential for the development of future therapies [13]. In recent years, many studies have demonstrated the therapeutic capacity of different stem cell populations.

Because of their easy accessibility and manipulation as well as their capacity to differentiate into a wide variety of other cell types; Bone marrow derived mesenchymal stem cells are promising for clinical applications as they are ideal vehicles for cellular gene transfer [14].

*Corresponding author: Abd Elwahab SA, Department of Histology, Faculty of Medicine, El-Minia University, Egypt, Tel: 002-086-01113069333; E-mail: aspb2017@gmail.com

Received March 22, 2017; Accepted May 05, 2017; Published May 15, 2017

Citation: Abd Elwahab SA, Hussein Ali A, Sayed Mahmoud A, Fathy Ahmed A, Soliman R (2017) Bone Marrow Derived Mesenchymal Stem Cell Therapy in Induced Acute Renal Injury in Adult Male Albino Rats. J Cytol Histol 8: 451. doi: 10.4172/2157-7099.1000451

Copyright: (C) 2017 Abd Elwahab SA, et al. This is an open-access article distributed under the terms of the Creative Commons Attribution License, which permits unrestricted use, distribution, and reproduction in any medium, provided the original author and source are credited. 
Aim of the present work is to study the possible reno-protective effects of BM-MSCs on induced acute kidney injury in a rat model of ischemia reperfusion, and to find out if there any difference in the outcome between local and systemic route of administration, using histological, immunohistochemical and biochemical methods.

\section{Materials and Methods}

\section{Experimental animals}

This study was conducted on 40 adult male spargue-dawley albino rats. They were 12 weeks old, weighing 150-200 g. The animals were housed in hygienic plastic cages and kept in clean well-ventilated room, with food and water ad-libitum. All animals' procedures were done according to the recommendation of El- Minia University Ethics committee for proper care and use of experimental animals.

Animals were divided into four groups, each group has 10 animals as follows

1) Group I (control sham-operated): 10 rats were subjected to sham operation, and then received intravenous saline.

2) Experimental group: 30 rats were subjected to renal ischemiareperfusion (I/R) injury by clamping both renal pedicles for $40 \mathrm{~min}$.

Rats were divided as follows:

A) Group II (untreated group): After removal of the clamps and visual confirmation of reflow. The animals received intravenous saline injection, and they were sacrificed after 3 days.

B) Group III: 10 rats received single intravenous injection of bromodeoxyuridine labeled BM-MSCs locally in renal cortex just after removal of the clamps and visual confirmation of reflow. They were sacrificed 3 days after removal of clamps.

C) Group IV (systemic treated group): 10 rats received single injection of MSCs in tail vein just after removal of the clamps and visual confirmation of reflow. They were sacrificed 3 days after MSCs injection.

\section{Preparation of Bone Marrow Derived Mesenchymal Stem cells}

The animals were anesthetized by halothane, and then the skin was sterilized with $70 \%$ ethyl alcohol before cutting the skin. The femurs and tibia were carefully dissected from adherent soft tissues. Then they were placed into sterilized beaker containing 70\% ethyl alcohol for 1-2 min. The bones were put in Petri dish contain Phosphate buffer saline 1X PBS (Hyclone, USA) for wash. The bones were taken to laminar air flow (unilab biological safety cabinet class II, china) to extract the BM. The two ends of the bones were removed using sterile scissors.

Bone marrow was collected by rapid infusion of the tibiae and femurs of 12 weeks adult male albino rats with Dulbecco's modified Eagles medium (DMEM) (lonza, Belgium) supplemented with $10 \%$ fetal bovine serum (FBS) (lonza, Belgium) and 1\% Antibiotic, Antimicotic (penicillin streptomycin) (lonza, USA). To isolate the nucleated cells density gradient ficol/paqu (pharmacia fine chemicals) was used. The isolated cells were cultured in $20 \mathrm{ml}$ complete media and incubated at $37^{\circ} \mathrm{C}$ in $5 \%$ humidified $\mathrm{CO}_{2}$ incubator (shellab, USA) for 7-10 days as primary culture or upon formation of large colonies. MSCs in tissue culture are fusiform in shape and adhesive to the polystyrene dish. Adherent MSCs were washed with phosphate buffered saline and dislodged from the cultured dish using Trypsin/EDTA solution, then centrifuged and re-suspended in cultured media enriched with serum $[15,16]$.

\section{Labeling of stem cells with bromodeoxyuridine dye}

MSCs were harvested during the $2^{\text {nd }}$ passage and were labeled with bromouridine fluorescent linker dye [17].

\section{Counting of cells}

Washed cells were resuspended in $1 \mathrm{ml}$ of appropriate media. From this cell suspension, $10 \mu \mathrm{l}$ was removed for counting. Depending on the estimated (using a microscope) cell number, a dilution factor between two and ten was used to count cells. Test the cell viability $10 \mu \mathrm{l}$ of cells was add to $10 \mu \mathrm{l}$ of Trypan blue $0.4 \%$ (lonza, USA) and mixed well. $10 \mu \mathrm{l}$ of the mixture was taken and put on hemocytometer (Neubauer, Germany) and cells were counted under ordinary microscope (Olympus CX31, USA). Then use this equation:

$\mathrm{NO}$ of cells $/ \mathrm{ml}=$ average of count cells $\times$ dilution factor $\times 10^{4}$

\section{Injection of MSCs}

Immediately after reflow, rats of group III received $0.5 \mathrm{ml}$ labeled MSCs $\left(2 \times 10^{5}\right)$ diluted with $1 \mathrm{ml}$ of saline, loaded in a $1 \mathrm{ml}$ sterile syringe and injected via tail vein for each rat [18]. Group IV received 2 $\times 10^{5}$ labeled MSCs diluted with $1 \mathrm{ml}$ of normal saline, loaded in a $1 \mathrm{ml}$ sterile syringe and injected systemically via tail vein for each rat [19].

\section{Induction of ischemia-reperfusion acute kidney injury}

Animals were anesthetized and Midline abdominal incision was done. Kidneys were exposed and renal pedicles were bilaterally clamped for $40 \mathrm{~min}$ to induce renal ischemia [20]. The clamps were then removed to allow kidney reperfusion. Kidneys were observed to ensure reflow. The incision was closed followed by topical application of antibiotic cream.

Sham operation: Sham-operated animals are subjected to the same steps without applying the clamps [21].

\section{Laboratory investigations}

Blood samples were collected from retro-orbital veins using capillary tubes. Urea and creatinine were measured for all rats, before and after the operation.

\section{Total RNA extraction and real time RT-PCR for TNFa and IL-6 gene expression}

Total RNA was isolated from renal tissue using RiboZol solution (Amresco, Solon, USA) according to the manufacturer's instructions. The relative purity of the isolated RNA was assessed spectrophotometrically, and the ratio of A260-A280 nm exceeded 1.8 for all preparations. Real-time PCR was performed using $5 \mu \mathrm{L}$ total RNA in a $25 \mu \mathrm{L}$ reaction containing $70 \mathrm{nM}$ of each primer and $12.5 \mu \mathrm{L}$ Sybr Green Real-time RT-PCR MasterMix (Thermo Scientific one step kits). Cycling conditions were $50^{\circ} \mathrm{C}$ for $2 \mathrm{~min}, 5 \mathrm{~min}$ at $95^{\circ} \mathrm{C}$, followed by 40 cycles of $30 \mathrm{~s}$ at $95^{\circ} \mathrm{C}, 30 \mathrm{~s}$ at $58^{\circ} \mathrm{C}$, and $30 \mathrm{~s}$ at $72^{\circ} \mathrm{C}$, and a final incubation for $5 \mathrm{~min}$ at $72^{\circ} \mathrm{C}$.

The primers for TNFa were 5'-TCC CAA CAA GGA GGA GAA GT-3' and 5'-TGG TAT GAA GTG GCA AAT CG-3', IL-6-primers were 5'-TGA TGG ATG CTT CCA AAC TG-3'and 5'-GAG CAT TGG AAG TTG GGG TA-3', and $\beta$-actin primers were 5'-GAG ACC TTC AAC ACC CCA GCC-3' and 5'-TCG GGG CAT CGG AAC CGC TCA-3'. 
Citation: Abd Elwahab SA, Hussein Ali A, Sayed Mahmoud A, Fathy Ahmed A, Soliman R (2017) Bone Marrow Derived Mesenchymal Stem Cell Therapy in Induced Acute Renal Injury in Adult Male Albino Rats. J Cytol Histol 8: 451. doi: 10.4172/2157-7099.1000451

Page 3 of 8

Values are expressed relative to a reference sample (calibrator): samples from the Sham animals. A mathematical model was used for the relative quantification of $T N F \alpha$ and $I L-6$ genes [22].

\section{Histological examination}

Light microscopic studies: At the end of the experiment, renal tissue specimens were cut into small pieces $2 \mathrm{~mm}$ each, fixed in $10 \%$ formalin solution for $48 \mathrm{~h}$, dehydrated in ascending grades of alcohol and embedded in paraffin. Serial sections of 5-6 $\mu \mathrm{m}$ thickness were cut, mounted on glass slides and subjected to the following techniques:

1. Examination of bromodeoxyuridine labelled MSCs using Fluorescent Microscope.

2. H\&E staining for histological examination.

3. Immunohistochemical staining for:-

a) Mouse monoclonal antibody for PCNA (proliferating cell nuclear antigen).

b) Mouse monoclonal antibody for Caspase-3 (for detection of apoptosis).

\section{Results}

\section{BM-MSCs localization into the renal tissue}

Sections from treated groups examined with fluorescent microscopy showed bromodeoxyuridine labelled cells homing into the renal tissue cortex and medulla (Figure 1).

\section{Hematoxylin and eosin-stained sections}

In the present study, H\&E stained sections of groups I (the control group) showed normal histological appearance of renal tissue, with renal corpuscles formed of tuft of glomeruli, Bowman's capsule including Bowman's space, proximal (PCT) and distal convoluted tubules (DCT). The lumina of the proximal convoluted tubules were narrow and were lined with pyramidal cells with basal striations, apical brush border and basal pale nuclei. The DCTs showed wider lumina and were lined with cubical cells with rounded central nuclei. Lining cells of DCTs ill-defined basal striations. Examination of renal medullary sections revealed normal histological architecture of loop of
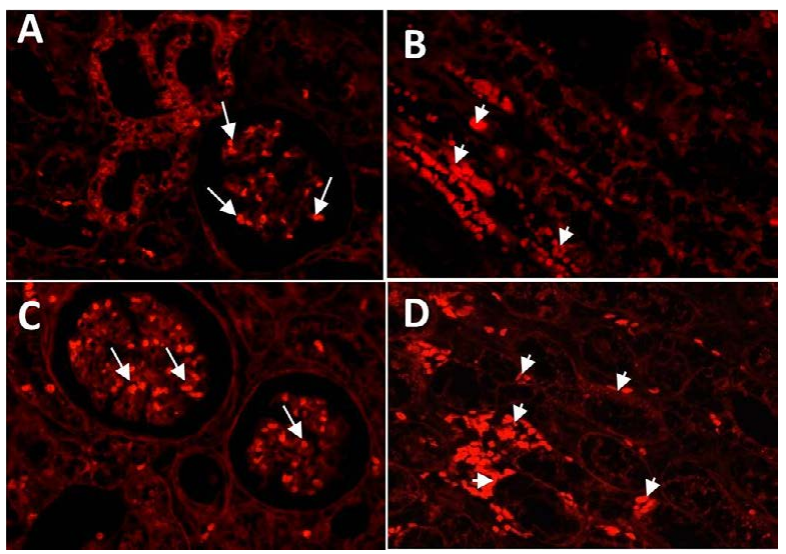

Figure 1: A photomicrograph of rat renal tissue of the treated groups showing: (A and B) group III MSCs labeled with bromodeoxyuridine are present within renal corpuscular cells (arrows) and among medullary lining tubular cells (arrowhead). (C and D) group IV (systemic injection) more labeled MSCs are present within renal corpuscular cells (arrow) and medullary lining tubular cells (arrowhead) (fluorescent microscopy X400).
Henel formed of thick descending limb similar in structure to PCT, thin descending and thin ascending limb lined with simple squamous epithelium and thick ascending limb similar in structure as DCT (Figure 2).

Examination of renal tissue of untreated group (II) showed degeneration of renal corpuscles with glomerular capillary congestion. Cytoplasm of the renal corpuscular cells showed vacuolations. In some cortical areas widening of Bowman's capsule could be observed. Tubular lining cells showed vacuolated cytoplasm and deeply stained nuclei. Peritubular capillary dilatation and congestion were observed in some cortical sections with inflammatory cell infiltration in the interstitial tissue. Acidophilic casts, and desquamated epithelial were detected in tubular lumina (Figure 3).

Sections of the renal tissue treated with MSCs through local injection showed decrease degeneration of renal corpuscle with decrease glomerular capillary congestion and slight dilatation of Bowman's space. Renal tubules tubular lining cells shows less vacuolated cytoplasm and less hyaline casts with decrease in peri-tubular capillary congestion.

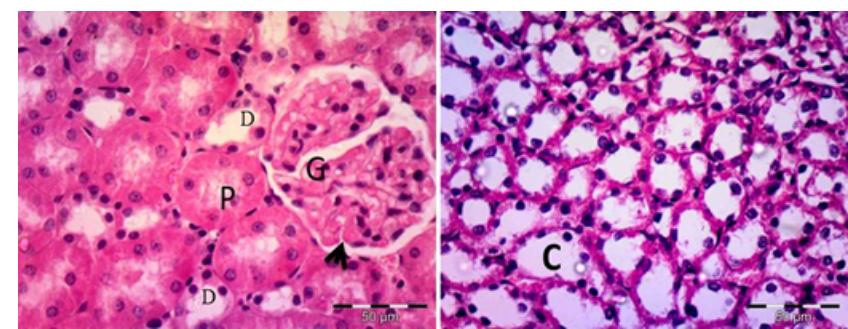

Figure 2: A photomicrograph of rat renal tissue of the group I (control shamoperated) showing Malpighian renal corpuscle containing glomerulus (G) surrounded by Bowman's space (arrow head). PCT (P) is lined with high cuboidal cells having rounded basal nuclei. DCT (D) is lined with cubical cells having rounded central nuclei. Collecting tubule (C) is lined with low cubical cells having rounded central nuclei (H and E X400).


Figure 3: A photomicrograph of rat renal tissue of the untreated group showing: A) Degeneration of renal corpuscles with widening of Bowman's space (arrow). B) Vacuolated cytoplasm \& darkly stained nuclei of tubular cells (arrow) Notice peritubular capillary dilatation and congestion (arrowhead). C) Tubular Lumina with desquamated epithelial cells and acidophilic hyaline casts $\left.{ }^{*}\right)$. D) Inflammatory cell infiltration in the interstitial tissue (arrow) $(\mathrm{H}$ and $\mathrm{E}$ X400 Scale bar $50 \mu \mathrm{m}$ ). 
Sections from the renal tissue treated with MSCs through systemic injection showed marked improvement in tissue architecture represented by well-formed renal corpuscles with normal glomerular tuft of capillaries, and nearly normal Bowman's space. The tubules showed absence of acidophilic casts and epithelial shedding from their Lumina (Figure 4).

\section{Immune histochemistry results}

\section{A) Caspase-3}

Immunohistochemistry for Caspase-3 showed negative expression in the normal renal tissue (Figure 5). Untreated group showed strong expression for Caspase- 3 in the cytoplasm and nuclei of cells in both renal cortex and medulla. There is a significant decrease in Caspase-3 expression after local treatment with MSCs, while faint and nearly negative expression is noticed in systemically treated group (Figure 6).

\section{B) PCNA}

Immunohistochemistry for PCNA showed some immune-positive nuclei in normal renal tissue (Figure 7). Both Untreated sections and MSCs locally treated sections showed some PCNA positive nuclei as well. While systemic MSCs treatment revealed marked increase in the number of PCNA positive nuclei (Figure 8).


Figure 4: A photomicrograph of the rat renal tissue treated with MCSs (A and B) group III local injection showing improvement of histological structure in both cortex and medulla. Improvement in histological appearance of renal corpuscle \& decrease glomerular capillary congestion (arrow), less cytoplasmic vacuolation of tubular lining cells (arrowhead). Notice: regression of intertubular congestion and inflammation $\left(^{*}\right)$. (C and D) Systemic injection with MSCs group IV showing nearly normal renal structure of both cortex and medulla. (H\&E X400 Scale bar $50 \mu \mathrm{m}$ ).


Figure 5: A photomicrograph of the rat renal tissue of control group showing negative Caspase-3 immunoreactivity in cytoplasm and nuclei of the renal corpuscular cells and medullary tubular lining cells. (Scale bar $50 \mu \mathrm{m}$ ).

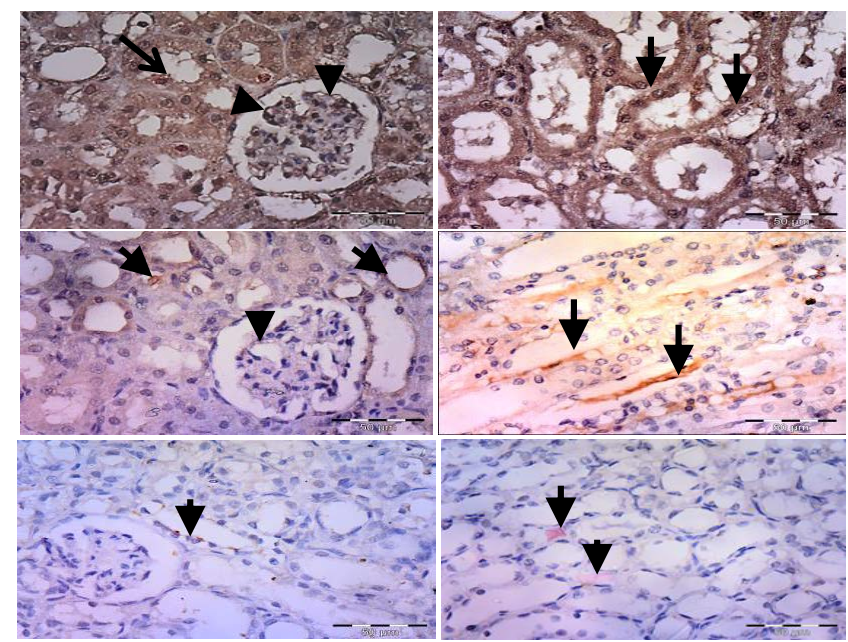

Figure 6: A photomicrograph of the rat renal tissue (A and B) group II shows strong Caspase-3 immunoreactivity in cytoplasm and nuclei of the renal corpuscular cells (arrowhead) and tubular lining cells in cortex and medulla (arrow). (C and D) group III showing mild Caspase-3 immunoreactivity in the cytoplasm of renal corpuscular cells (arrowhead) and tubular lining cells (arrow). Notice negative nuclear expression. ( $E$ and F) group IV showing very few immunoreactive.



Figure 7: A photomicrograph of the rat renal tissue of control group showing some positive PCNA nuclei of the renal corpuscular cells (arrow) and among the medullary tubular lining cells $\left(^{*}\right)$. (PCNA X400 Scale bar $50 \mu \mathrm{m}$ ).

\section{Results of real time RT-PCR for $T N F \alpha$ and $I L-6$ gene expression}

The fold changes in the gene expression for TNF $\alpha$ and $I L-6$ were detected by Real-Time PCR and the concentration for each practical test was normalized to its $\beta$-actin reference gene. Each test also was done in triplicate for the all samples. The mean values and standard errors were calculated and showed in Chart 1.

In the $3^{\text {rd }}$ day of operation $T N F \alpha$ and $I L-6$ genes were expressed less in the IR with local stem cells $(2 \pm 0.3$ and $1.6 \pm 0.87)$, respectively and IR with systemic stem cells group ( $1.6 \pm 0.43$ and $1 \pm 0.77)$ respectively than IR $(6.9 \pm 0.93$ and $6.5 \pm 0.77)$ respectively.

\section{Biochemical results}

Serum levels of urea and creatinine showed significant increase in untreated group, while treated groups (local and systemic with MSCs) showed marked improvement in these biochemical parameters. In the systemic treated group urea was nearly back to normal (Tables 1 and 2).

\section{Quantitative morphometric results}

Mean number of PCNA positive nuclei $( \pm S D)$ in the studied groups: No significant increase in the number of PCNA positive nuclei in group III (local treatment with MSCs) compared with group 


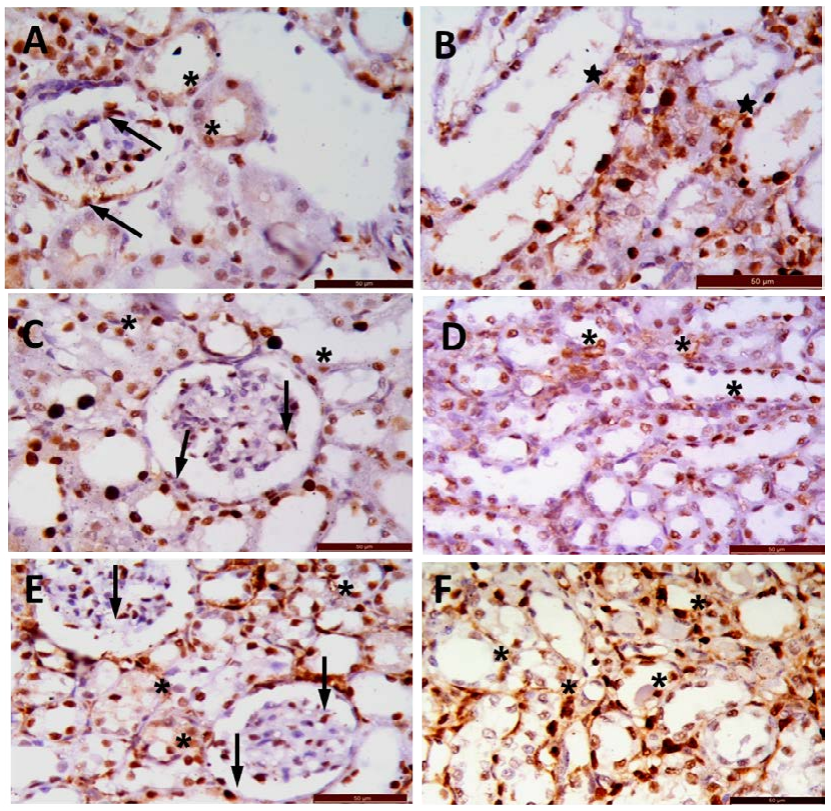

Figure 8: A photomicrograph of the rat renal tissue (A and B) group II showing some PCNA immuno- reactive nuclei in the renal corpuscular cells (arrow) and among the tubular lining cells in cortex and medulla $\left({ }^{*}\right)$. (C and D) group III showing some PCNA immuno-reactive nuclei in renal corpuscles (arrow) and among tubular lining cells $\left(^{*}\right)$. (E and F) group IV showing multiple PCNA positive nuclei in renal corpuscles (arrow) and among tubular lining cells $\left({ }^{*}\right)$. (PCNA X400 Scale bar $50 \mu \mathrm{m}$ ).

\section{Comparison among different groups}

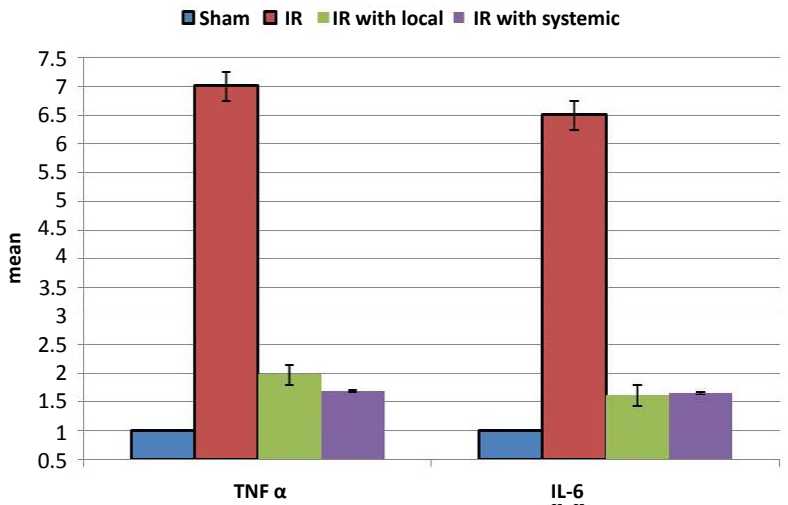

Chart 1: Representing the differences between studied groups in proinflammatory Cytokines production gene $(p<0.05)$.

II (untreated group). The highest value for PCNA positive nuclei was recorded in group IV (MSCs systemically treated group) with high statistically significant increase in the number of PCNA positive nuclei in this group compared to group II \&III ( $\mathrm{p}<0.05)$ (Table 3 and Chart 2).

\section{Mean area\% of Caspase-3 positive cells $( \pm$ SD) in the studied groups}

Mean area\% of Caspase-3 immuno-reactivity in cortical and medullary tubular cells of groups II and III showed a significant decrease $(p<0.05)$ when compared to control. There is significant difference between group III and group IV (Table 4).

\begin{tabular}{|c|c|c|c|}
\hline $\begin{array}{c}\text { Control group } \\
\text { (group I) }\end{array}$ & $\begin{array}{c}\text { Untreated group } \\
\text { (group II) }\end{array}$ & $\begin{array}{c}\text { locally Treated } \\
\text { group (group III) }\end{array}$ & $\begin{array}{c}\text { Systemically } \\
\text { treated group } \\
\text { (group IV) }\end{array}$ \\
\hline $32.3 \pm 2$ & $90.1 \pm 2$ & $42 \pm 3$ & $33.2 \pm 2$ \\
\hline \multicolumn{3}{|c|}{ Table 1: A Significantly different $p<0.05}$. \\
\hline $\begin{array}{c}\text { Control group } \\
\text { (group I) }\end{array}$ & $\begin{array}{c}\text { Untreated group } \\
\text { (group II) }\end{array}$ & $\begin{array}{c}\text { locally Treated } \\
\text { group (group III) }\end{array}$ & $\begin{array}{c}\text { Systemically } \\
\text { treated group } \\
\text { (group IV) }\end{array}$ \\
\hline $0.81 \pm 0.2$ & $3.46 \pm 0.7$ & $2.21 \pm 0.5$ & $1.1 \pm 0.3$ \\
\hline & Table 2: A Significantly different $p<0.05$. \\
\hline
\end{tabular}

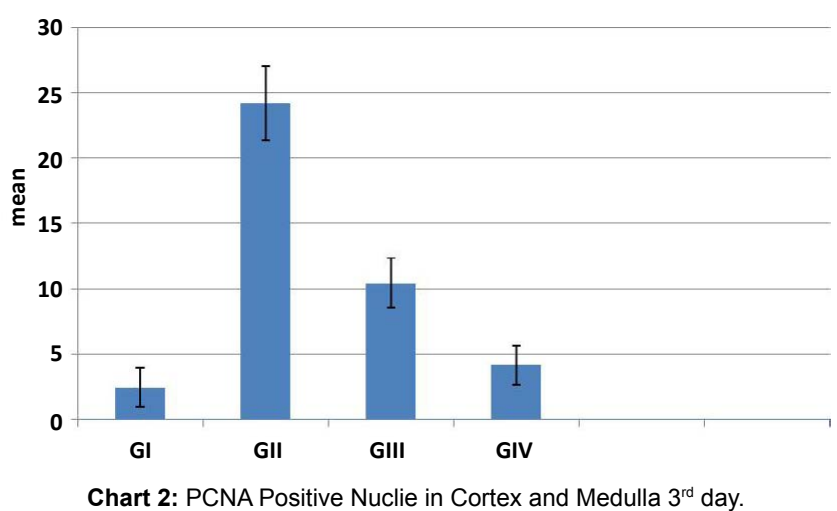

\section{Discussion}

Ischemic-reperfusion (I/R) injury is the most common cause for acute renal failure, warrants the urgent development of new treatment modalities. Recent studies introduce bone marrow derived cells (MSCs) as a new therapeutic rationale for acute renal injury. In the present study we used ischemic reperfusion method to induce acute renal injury in rats, MSCs labeled with bromodeoxyuridine fluorescent linker dye injected through two different routes (systemic and cortical injection) to evaluate their therapeutic effect biochemically and histologically.

Biochemical results of untreated group (II) showed marked impairment of the renal function with high plasma level of urea and creatinine. Histological sections of the same group showed widening of the capsular space, shrinkage of glomerular tuft and inter-glomerular hemorrhage. Tubular cells showed vacuolated cytoplasm, pyknotic nuclei, and hyaline casts. Desquamated epithelial cells were observed in tubular lumen of both cortex and medulla. Acute renal injury is manifested by both serological and histological findings in renal cortex and medulla [23-25]. In our study homing of MSCs to the damaged renal tissue in the treated groups (III \&IV) was confirmed by examination with the fluorescent microscopy, labeled cells appeared immediately in the cortical corpuscles and in the peri-tubular spaces. In rat model of AKI through 40 min bilateral clamming of renal pedicle, fluorescence-labeled MSC were detected early after injection in glomeruli, and at microvasculature sites [26]. In mice animal model of acute renal ischemia, MSCs transplanted into mice selectively grafted onto damaged area [27].

In the present study MSCs treated groups showed marked improvement in renal function parameters especially in systemic injected group; in which the plasma level of urea and creatinine nearly back to normal level 3 days after injection. In clinical trial conducted on 30 patients with acute kidney injury, serum urea and creatinine decreased significantly after MSCs injection, and renal functions had 


\begin{tabular}{|c|c|c|c|c|c|c|}
\hline $\begin{array}{c}\text { PCNA positive } \\
\text { nuclei } \\
\text { P-value }\end{array}$ & \multicolumn{2}{|c|}{$2 \pm 1.2$} & $4.4 \pm 1.9$ & \multicolumn{2}{|c|}{$5.4 \pm 1.5$} \\
\hline & I vs. II & I vs. III & II vs. III & I vs. IV & II vs. IV \\
\hline & 0.3 & $0.01^{*}$ & 0.7 & $0.01^{*}$ \\
\hline
\end{tabular}

Table 3: Mean number of PCNA positive nuclei $( \pm S D)$ in the studied groups.

\begin{tabular}{|c|c|c|c|c|c|c|}
\hline $\begin{array}{l}\text { Cortex and medulla } 3^{\text {rd }} \\
\text { day }\end{array}$ & \multicolumn{2}{|c|}{ Control } & Untreated & \multicolumn{2}{|c|}{ Local treatment } & Systemic treatment \\
\hline $\begin{array}{c}\text { Caspase } 3 \text { positive } \\
\text { cells }\end{array}$ & $2.5 \pm 1.51$ & \multicolumn{2}{|c|}{$24.2 \pm 2.85$} & \multicolumn{2}{|c|}{$10.5 \pm 1.87$} & $4.2 \pm 1.47$ \\
\hline \multirow[t]{3}{*}{ P-value } & \multicolumn{6}{|c|}{$0.001^{*}$} \\
\hline & I vs. II & I vs. III & II vs. III & I vs. IV & II vs. IV & III vs. IV \\
\hline & $0.001^{*}$ & $0.001^{*}$ & $0.001^{*}$ & 0.1 & $0.001^{*}$ & $0.03^{*}$ \\
\hline
\end{tabular}

Table 4: Mean area\% of Caspase-3 positive cells ( \pm SD) in the studied groups.

been restored [28]. Other results stated that MSCs administration to rats with acute kidney injury significantly restored renal functional parameters and hastened functional recovery $[27,29,30]$.

Histological manifestations of renal damage showed marked improvement after MSCs injection. The histological improvement was more evident in group (IV) which was treated with systemic administration of MSCs. Less tubular necrosis, less tubular casts and fewer desquamated cells within tubular lumen. In cisplatin-treated rats MSCs infusion prevented occurrence of AKI through down regulation of tubular cell apoptosis and enhancing proliferation [31].

The Peri-tubular dilatation and congestion observed in the untreated group; showed improvement after local infusion of MSCs and completely disappeared after their systemic infusion. This was explained with the pro-angiogenic ability of MSCs and their ability to induce five folds increase in the level of vascular endothelial cell growth factors (VEGF) when administrated to the mice with acute renal ischemia [32,33]. MSCs can induce angiogenesis by supporting the new vasculature and maintain renal perfusion or by producing growth factors associated with the angiogenesis process as vascular endothelial growth factor (VEGF) insulin-like growth factor (IGF), and plateletderived growth factor (PDGF) [29].

In our study inflammatory cell requirement to the renal tissue showed marked regression after MSCs infusion, furthermore systemic infusion showed complete absence of inflammatory cells from the examined sections of the treated group (IV).

The same findings were described in others work who studied the anti-inflammatory/Immunomodulatory properties of MSCs in AKI and stated that inflammatory cells as macrophages, neutrophils and T cells can enhance the development of AKI [34]. MSCs move to sites of inflammation and release trophic growth factors to modulate the immune system, modulate macrophages activity and provide renal protection and repair [35].

Our results showed improvement of renal function was associated with reduced expression of pro-inflammatory cytokines (IL-6, TNF- $\alpha$ ) in 3rd day after local and systemic MSCs application $(\mathrm{P}<0.001)$. Regarding TNF- $\alpha$ expression, systemic treatment was significantly lower than local injection MSCs application resulting in downregulation of pro-inflammatory cytokines [36].

MSCs have strong immune-modulatory action on immune cells through cell-to-cell contacts through production of cytokines, chemokines and growth factors [37]. In allogeneic co-culture assay MSCs inhibit the ability of dendritic cells to stimulate $\mathrm{T}$ cell proliferation and reduce B cell activity, it is well known that both immune cells (dendritic and B cell) have an important role in the development of AKI [38]. MSCs have numerous possible immune regulatory functions enable them to ameliorate kidney inflammation and improve the outcome of AKI [39].

In our study, immunohistochemical staining for Caspase-3 as an apoptotic marker was done to detect confirm apoptosis in renal cells in the kidney sections. The results showed that the number of Caspase-3 positive cells in the kidney tubules in cortex and medulla markedly increased in group II while in group III and IV the infusion of BMMSCs significantly decrease the number of apoptotic cells. Other studies also observed down-regulation of Caspase- 3 in MSCs treated groups [25].

In this study, immuno-histochemical staining for PCNA was done to measure cellular proliferation and renal tissue regeneration. BM-MSCs significantly increased the number of PCNA-positive cells, suggesting that BM-MSCs stimulate cell proliferation of renal tubular cells.

After an ischemic injury to the kidney in group II, sections of renal cortex showed many positive PCNA immuno-reactive nuclei of renal corpuscular cells and also among renal tubular lining cells in renal cortex and medulla when compared with control group. This agrees with other studies which stated that MSC injection help the recovery of renal function by stimulation of tissue proliferation [33].

The number of immuno-positive nuclei for PCNA wasincreased after MSCs administration especially in systemic group. This is in agreement with recent studies which explained the renal tubular protective effect of BM-MSCs by its potential ability to Trans-differentiate [40]. The same results are in disagreement with other studies stated that BMMSCs moved into injured renal tissue have no chance to differentiate into renal cells; as they were mainly localized in peri-tubular areas, not within the tubules. Large number of undifferentiated cells is localized within the normal renal tissue [41]. Renal papillae, epithelium of the tubules, and parietal layer of Bowman's capsule are the main sites for renal progenitor cells [42-44].

The normal progenitor cells within the renal tissue markedly increase in number following renal injury suggesting their important role in renal repair. After restoration of normal renal function the number of renal progenitor cells back to its normal ratio [45,46]. MSCs release extracellular rmicrovesicles (MSC-EVs) with small RNAs content, miRNA is expected to have a reno-protective effect [47-49]. 
The RNA content of MSCs extracellular microvesicles is small non coding RNA of 21-25 nucleotides in length. This molecule is directed to the damaged cells and can regulate their gene expression pattern towards regeneration $[35,50]$.

The present study provided evidence that BM-MSCs when administered systemically have a better protective effect on the renal tissue than locally administrated cells. More experimental studies are still needed for better understanding of the different mechanisms through which MSCs induce their therapeutic effects on the damaged renal tissue. Controlled clinical trials should be done in parallel.

\section{References}

1. Bussolati B, Hauser PV, Carvalhosa R, Camussi G (2009) Contribution of stem cells to kidney repair. Curr Stem Cell Res Ther 4: 2-8.

2. Pavenstädt H, Kriz W, Kretzler M (2003) Cell biology of the glomerular podocyte. Physiol Rev 83: 253-307.

3. Song B, Smink AM, Jones CV, Callaghan JM, Firth SD, et al. (2012) The directed differentiation of human iPS cells into kidney podocytes. PLoS One 7: e46453.

4. Bellomo R, Kellum JA, Ronco C (2012) Acute kidney injury. Lancet 380: 756-766.

5. Chawla LS, Eggers PW, Star RA, Kimmel PL (2014) Acute kidney injury and chronic kidney disease as interconnected syndromes. N Engl J Med 371: 58-66.

6. Saddadi F, Najaf I, Hakemi MS, Falaknazi K, Attari F, et al. (2015) "Frequency, risk factors, and outcome of acute kidney injury following bone marrow transplantation at Dr Shariati Hospital in Tehran,". Iranian J Kidney Dis 4: 20-26.

7. Nagaya N, Fujii T, Iwase T, Ohgushi H, Itoh T, et al. (2004) Heart and Circulatory Physiology. Am J Physiol 87: H2670-H2676.

8. Shu SN, Wei L, Wang JH (2004) Hepatic differentiation capability of rat bone marrow-derived mesenchymal stem cells and hematopoietic stem cells. World J Gastroenterol 10: 2818-2822.

9. Singaravelu K, Padanilam BJ (2009) In vitro differentiation of MSC into cells with a renal tubular epithelial-like phenotype. Ren Fail 31: 492-502.

10. Ortiz LA, Gambelli F, McBride C, Gaupp D, Baddoo M (2004) Mesenchymal stem cell engraftment in lung is enhanced in response to bleomycin exposure and ameliorates its fibrotic effects. Proc Natl Acad Sci USA 100: 8407-8411.

11. Frank MH, Sayegh MH (2008) Immunomodulatory functions of mesenchymal stem cells. Lancet 363: 1411-1412.

12. Deans RJ, Moseley AB (2015) Mesenchymal stem cells: Biology and potential clinical uses. Exp Hematol 28: 875-884.

13. Javazon EH, Colter DC, Schwarz EJ, Prockop DJ (2001) Rat marrow stroma cells are more sensitive to plating density and expand more rapidly from singlecell-derived colonies than human marrow stromal cells. Stem Cell 19: 219-25.

14. Lee P, Chien Y, Chiou G, Lin C, Chiou C, et al. (2012) Induced pluripotent stem cells without c-Myc attenuate acute kidney injury via down regulating the signaling of oxidative stress and inflammation in ischemia-reperfusion rats. Cell Transplant 21: 2569-2585.

15. Alhadlaq A, Mao JJ (2004) Mesenchymal stem cells: isolation and therapeutics. Stem Cells Dev 13: 436-448.

16. Rochefort GY, Vaudin P, Bonnet N, Pages JC, Domenech J, et al. (2005) Influence of hypoxia on the domiciliation of mesenchymal stem cells after infusion into rats: possibilities of targeting pulmonary artery remodeling via cells therapies? Respir Res 6:125

17. Zhou T, X-N Cen, Z-X Qiu (2009) "Clinical analysis of acute renal failure after allogeneic hematopoietic stem cell transplantation." Zhongguo Shi Yan Xue Ye Xue Za Zhi 17: 723-728.

18. Cavaglieri RC, Martini D, Sogayar MC, Noronha IL (2009) Mesenchymal Stem Cells Delivered at the Subcapsule of the KidneyAmeliorate Renal Disease in the Rat Remnant Kidney Model”. Elsevier Inc 13: 947-951

19. Morigi M, Imberti B, Zoja C, Corna D, Tomasoni S, et al. (2014) Mesenchyma stem cells are renotropic, helping to repair the kidney and improve function in acute renal failure. J Am Soc Nephrol 15: 1794-1804.
20. Tögel F, Hu Z, Weiss K, Isaac J, Lange C (2004) Administered mesenchyma stem cells protect against ischemic acute renal failure through differentiationindependent mechanisms. Am J Physiol Renal Physiol 289: 31-42.

21. Hagiwara M, Shen B, Chao L, Chao J (2008) Kallikrein-modified mesenchymal stem cell implantation provides enhanced protection against acute ischemic kidney injury by inhibiting apoptosis and inflammation. Hum Gene Ther 19 807-819.

22. Pfaffl MW (2001) A new mathematical model for relative quantification in realtime RT-PCR. Nucleic Acids Res 29: e45.

23. Bassi EJ, Almeida DC, Moraes-Vieira PM, Saraiva NO (2012) Exploring the Role of Soluble Factors Associated with Immune Regulatory Properties of Mesenchymal Stem Cells. Stem Cell Rev Rep 8: 329-342.

24. Kusaba T, Lalli M, Kramann R, Kobayashi A, Humphreys BD (2014) "Differentiated kidney epithelial cells repair injured proximal tubule." Proceedings of the National Academy of Sciences of the United States of America 111: 1527-1532.

25. Lui PPY, O Wong OT, Lee YW (2016) Transplantation of Tendon-Derived Stem Cells Pre-Treated With Connective Tissue Growth Factor and Ascorbic Acid in Vitro Promoted Better Tendon Repair in a Patellar Tendon Window In Rat Model. Cytotherapy 18: 99-112.

26. Tögel F , Isaac J, Hu, Weiss K, Westenfelder C (2005) Renal SDF-1 signals mobilization and homing of CXCR4-positive cells to the kidney after ischemic. Kidney International 67: 1772-1784.

27. Barnes CJ, Distaso CT, Spitz KM, Verdun VA, Haramati A (2016) Comparison of stem cell therapies for acute kidney injury. Am J Stem Cells 5: 1-10.

28. Saadi G, El Ansary ME, Hassaballa MA, Roshdy M, A El-Aziz E (2016) Vascular endothelial growth factor and insulin growth factor as an underlying paracrine action of mesenchymal stem cells transfused for the regeneration of stage II and III chronic kidney disease. Egyptian J Nephrol Transplant 16: 3-9.

29. Tögel F, Cohen A, Zhang P, Yang Y, Hu Z (2009) Autologous and Allogeneic Marrow Stromal Cells Are Safe and Effective for the Treatment of Acute Kidney Injury. Stem Cell Dev 18: 475-486.

30. Rao S, Walters KB, Wilson L, Chen Bo, Bolisetty S (2016) Early lipid changes in acute kidney injury using SWATH lipidomics coupled with MALDI tissue imaging. Am J Physiol Renal Physiol.

31. Kim HS, Choi DY, Yun SJ, Choi SM, Kang JW (2012) Proteomic analysis of microvesicles derived from human mesenchymal stem cells. J Proteome Res 11: 839-849.

32. Krishnappa V, Gupta M, Manu G, Kwatra S, Owusuand OT (2016) Acute Kidney Injury in Hematopoietic Stem Cell Transplantation. Int J Nephrol p: 13

33. Bianchi F, Sala E, Donadei C, Capelli I, La Manna G (2014) Potentia advantages of acute kidney injury management by mesenchymal stem cells. World J Stem Cell 6: 644-50.

34. Maeshima A, Takahashi S, Nakasatom M, Nojima Y (2015) Diverse cell populations involved in regeneration of renal tubular epithelium following acute kidney injury. Stem Cell Int.

35. Yao K, Ricardo CD (2016) Mesenchymal stem cells as novel micro-ribonucleic acid delivery vehicles in kidney disease. 21: 363-371.

36. Hara Y, Stolk M, Ringe J, Dehne T, Ladhoff J (2011) In vivo effect of bone marrow-derived mesenchymal stem cells in a rat kidney transplantation model with prolonged cold ischemia. Transpl Int 24: 1112-1123.

37. Obermajer N, Felix C Popp, Soeder Y, Haarer J, Edward KJH (2014) Conversion of Th17 into IL-17Aneg Regulatory T Cells: A Novel Mechanism in Prolonged Allograft Survival Promoted by Mesenchymal Stem Cell-Supported Minimized Immunosuppressive Therapy. J Immunol 193: 4988-4999.

38. Griffin MD, Ryan AE, Alagesan S, Lohan P, Treacy O (2013) Anti-donor immune responses elicited by allogeneic mesenchymal stem cells: what have we learned so far? Immunol Cell Biol 91: 40-51.

39. Casiraghi F, Perico N, Cortinovis M, Remuzzi G (2016) Mesenchymal stroma cells in renal transplantation: opportunities and challenges. Nat Rev Nephrol 12: $241-253$.

40. Bergera K, Bangenb JM, Hammerichb L, Floegea CL, Smeetsa B, et al. (2014) Origin of regenerating tubular cells after acute kidney injury. Proc Natl Acad Sci U S A (PNAS) 111: 1533-1538. 
Citation: Abd Elwahab SA, Hussein Ali A, Sayed Mahmoud A, Fathy Ahmed A, Soliman R (2017) Bone Marrow Derived Mesenchymal Stem Cell Therapy in Induced Acute Renal Injury in Adult Male Albino Rats. J Cytol Histol 8: 451. doi: 10.4172/2157-7099.1000451

Page 8 of 8

41. Kang M, Han Y-M (2014) Differentiation of Human Pluripotent Stem Cells into Nephron Progenitor Cells in a Serum and Feeder Free System.

42. Oliver JA, Maarouf O, Faisal H, Cheema FH, Martens TP (2004) The renal papilla is a niche for adult kidney stem cells. J Clin Invest 114: 795-804.

43. Erin A Kimbrel, Robert L (2015) Current status of pluripotent stem cells: moving the first therapies to the clinic. Nat Rev Drug Disc 14: 681-692.

44. Sagrinati C, Netti GS, Mazzinghi B, Lazzeri E, Liotta F (2006) Isolation and Characterization of Multipotent Progenitor Cells from the Bowman's Capsule of Adult Human Kidneys. JASN 17: 2443-2456.

45. Takasato M, Er PX, Becroft M, Vanslambrouck JM, Stanley EG (2014) Directing human embryonic stem cell differentiation towards a renal lineage generates a self-organizing kidney. Nat Cell Biol 16: 118-126.

46. Park HC, Yasuda K, Ratliff B, Stoessel A, Sharkovska Y (2010) Postobstructive regeneration of kidney is derailed when surge in renal stem cells during course of unilateral ureteral obstruction is halted. Am J Physiol Renal Physiol 298: F357-F364.

47. Ranghino A, Bruno S, Bussolati B, Moggio A, Dimuccio V (2017) The effects of glomerular and tubular renal progenitors and derived extracellular vesicles on recovery from acute kidney injury. Stem Cell Res Ther 8: 24.

48. Lindoso RS, Araujo DS, Adão-Novaes J, Mariante RM, Verdoorn KS (2011) Paracrine Interaction between Bone Marrow-derived Stem Cells and Renal Epithelial Cell Physiol Biochem 28: 267-278.

49. Morigi M, Rota C, Remuzzi G (2016) Mesenchymal Stem Cells in Kidney Repair. Methods Mol Biol 1416: 89-107.

50. Chen CL, Chou KJ, Fang HC, Hsu CY, Huang WC (2015) Progenitor-like cells derived from mouse kidney protect against renal fibrosis in a remnant kidney model via decreased endothelial mesenchymal transition. Stem Cell Res Ther Dec 2: 239. 